
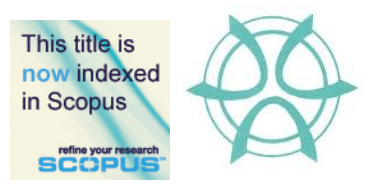

PLANNING MALAYSIA:

Journal of the Malaysian Institute of Planners

VOLUME 15 VOLUME 1 (2017), 327 - 332

\title{
THE INTEGRATION OF MOSQUES AND CHURCHES TO URBAN PLANNING OF IBADAN NIGERIA: A HISTORICAL OVERVIEW
}

\author{
Ibraheem Mikail Abiola ${ }^{1}$ \\ ${ }^{1}$ Kulliyyah of Islamic Revealed Knowledge and Human Sciences \\ INTERNATIONAL ISLAMIC UNIVERSITY MALAYSIA
}

\begin{abstract}
In the face of the uncontrolled expansion of Nigerian towns and cities since independence, urban planners and other stakeholders have accepted that development policies for urban and rural areas have failed or have not worked as expected. Cities in Nigeria, especially, Ibadan have been observed to have changed in size, spatial organization or morphology, quality and distribution of public services and infrastructure, and in its employment base. Despite many efforts aimed at resolving the urban problems through the enactment of plethora of planning laws and regulations, the administration and implementation of these laws and regulation have been problematic, especially due to the rapid increase of religious sites (places of worship) such as churches and mosques in Ibadan. The objective of this paper is to propose a solution to the problems created by religious sites in the planning of Ibadan. The study employs a qualitative research design using survey method, with field observation as the research instrument used for data collection.
\end{abstract}

Keyword: Nigeria, Ibadan, urban, rural, mosques, churches.

Date Received: $30^{\text {th }}$ April 2016

Date of Acceptance: $30^{\text {th }}$ October 2016 
Ibraheem Mikail Abiola

The Integration of Mosques and Churches to Urban Planning of Ibadan Nigeria: A Historical Overview

\section{INTRODUCTION}

Ibadan is located and situated in the southwestern part of Nigeria, in the southeastern part of Oyo state, about $120 \mathrm{~km}$ east of the border with the Republic of Benin. The city total area is $1,190 \mathrm{sq}$ miles $\left(3,080 \mathrm{~km}^{2}\right)$. The city is naturally drained by four rivers which have many tributaries i.e. streams flowing into larger lake: Ona River on the north and west, the Ogbere River towards the east, Ogunpa flowing through the city and Kudeti River in the central part of Ibadan metropolis.

In 1931, less than $7 \%$ of Nigerians lived in planned urban centres. Over a period of exactly 30 years (1952-1982), the population in significant Nigerian towns has increased. For example, in the city of Ibadan, it rose from 625,000 in 1963 to 2.8 million in 1982 (Adekilekun, 2001). The people were scattered all over Ibadan in areas that are not properly planned, and in building that are not structurally sound. More easily observable is the lack of Islamic principle in rapid urban growth in Ibadan. This paper examines the historical analysis of urban planning in Ibadan, Nigeria, from 1960 to 2010, with special emphasis on its presumed Islamic connection. It explores factors that have contributed in shaping the planning of urban settlements, in addition to the influence of local topography and morphological features of pre-existing cities such as Ibadan.

\section{RESEARCH METHODOLOGY}

This study looks into an extant historical phenomenon of an urban planning. It adopts a qualitative research design using survey method. Data were obtained through site observation and also from secondary sources. Content analysis method was employed to analyse the data.

\section{INTEGRATION OF MOSQUES AND CHURCHES INTO URBAN PLANNING IN IBADAN}

\section{Integration of Mosques}

Obviously, in view of the pledge of Islam to provide a house in paradise for whoever builds a mosque, Ibadan Muslims have individually and collectively put up structures of different sizes, designs and magnitude for praying purposes. Doi (1984), Adekilekun (2001) and Agbetola (1999) have given an account in their work of the origin, development and administration of the mosques in the southwestern part of Nigeria. Agbetola (1999), in his account writes that the early Muslims merely chose a clean spot to spread their animal skins, mostly ram, and mats to establish their prayers. Later, a marked off area with a fence made from sand emerged; "this is the Musallah, the Yoruba Ibadan called it Masalasi" (Agbetola, 1999).

"The Masalasi gave way to small permanent structure known as the real Masjid (English: Mosque) because it had structures and a few facilities. The development of the simple form of thatched roof hut resting on four or six 
PLANNING MALAYSIA:

Journal of the Malaysia Institute of Planners (2017)

forked sticks similarly gave way to one supported by mud walls. This was a real building, but with a design of open windows and door ways of no security... This structure also with time developed into modest architectural design with facilities such as modest minarets. They carried simple designs of Muslim traditional slate (Arabic Lawh) on the roof or minaret as the sign for a Muslim place of worship."

Doi (1984) however, writes about the decorations given to mosques by the Ibadan Muslims:

"The decoration in the mosque buildings is simple, but most eye-catching, restrained according to the principles of Islamic art and architecture, and avoids the use of icons or even the slightest resemblance to any living animal or insect..."

He continues:

"The mosques are planned with such great dexterity that at a given time, one can see only one or two decorations because of the contrast of light and shadow in the total scheme of the construction", (Doi, 1984).

Nevertheless, Doi (1084) also observes that some mosques were decorated with icons contrary to Islamic principles by having decorative elephants on the top of the mosques. He also claims that the icons had been removed thereafter. Agbetola (1999) also gives some pictorial views of some mosques in Ibadan and environs. However, this study contains of pictures which cut across central, community (ratibi), institutional, organizational and government house mosques in Agodi Ibadan (Doi, 1984).

However, based on observation made on site, some of the present mosques, such as the Aare Abdul Azeez Arisekola Central Mosque, Iwo-road Ibadan and Adeojo Mosque along Lagos-Ibadan express way are more impressive than those described by Agbetola (1999) and Doi (1984). Some of these mosques are even up to three-storey high. Some mosques, such as the Shamsu-suud mosque, Omowumi-Olorunsogo, Ibadan have tall minarets built using stones or concrete. Others have minarets carrying domes against the flat head of the mosques, with the demands of modern time such as parking space, social hall, and committee room (Akintola, 2004). Many mosques, particularly the early ones, do not have space for such facilities. Some of these mosques were built within compounds obviously for family use, while others were constructed close to the road and lined up in the streets of Ibadan, leaving barely trek able distance to one another. For example, the Ayegoro mosque could hardly be distinguished from residential buildings. In fact, the distinguishing factor between a part of a building used as a mosque and that used as residence is the loudspeaker which, as in other mosques, is located on top of the mosques or beside or within the 
Ibraheem Mikail Abiola

The Integration of Mosques and Churches to Urban Planning of Ibadan Nigeria: A Historical Overview

walls. There have been issues generated between the Muslim community and non-Muslims who feel that the loudspeakers are being abused by some mosques within Ibadan and other cities in Nigeria. Also, some mosques are built close to the main roads and left the road users with narrow roadway, which escalate obstructions and blockage of road during the large turnout of worshippers on Fridays and when there are some other occasions within the mosque premises (Liadi, 2001).

\section{Church Integration}

In the 1970s, when orderliness reigned in Ibadan, churches were built with maximum conformity to planning regulations, societal overall aesthetic appeal, beauty and comfort of users and neighbours (Joseph, 1997). Aside from the expansive worshipping area, ample parking spaces were provided to discourage street parking and minimize the likely inconvenience to other road users. Within the church precinct, it was conventional and traditional to find houses for the leadership and church workers, and small scale or small size commercial building to generate income to support the church activities. In some churches, complementary buildings, such as schools and clinics, which provide services to the immediate and remote communities could be found (Shope, 1954).

Between 1975 to 1979 , the Ibadan population rose and church development had kept pace with this growth without any adverse effort on the urban planning system, urban infrastructure and societal psyche. Among the then prominent churches were Catholic, Anglican, Methodist, Jehovah witness, Seventh Day Adventise, Apostolic and Redeem among others. The downfall of the Nigerian economy in the 1980s and subsequent political crisis of 1993 were the impetus for a substantial number of manufacturing industries within Ibadan to terminate their productions (Iyanda, 2004). In the wake of this development, many manufacturing sites and warehouses were left vacant.

The inability of the Urban Planning Ministry to be pro-active on the best alternative uses of those abandoned premises provided a veritable platform for churches. As a result, the stretch of Oluyole estate roads to Challenge Elewura, Iwo Road to Basorun were littered with flags and banners of different churches. The conversion of the industrial premises and private houses into churches in Ibadan had created a severe traffic burden for the city since the emerging scenario was not envisaged during the presentation of Ibadan master plan. With the end of the manufacturing sector and growth of population within Ibadan metropolis, poverty incidence increased, and the cry for divine intervention became louder. Churches in Ibadan continue to expand on the old denominations as well as the erection of new ones. For example, The Redeemed Christian Church has over 100 branches within Ibadan (Kabir, 2006).

The demand for industrial premises and warehouses to be converted into churches became enormous. Consequently, the price of those premises rose to 
astronomical rate and was no longer affordable, hence recourse to residential area. Although the foray is more pronounced in residential areas, it is not limited to this stretch of land or zone. Business premises such as quick service restaurants, cinemas, like Baba Sala cinema at Agbowo, and merchandising shops, were not spared. Currently, the presence of churches in residential areas within Ibadan has significantly depleted the housing stock available to the populace, in a city grappling with an estimated hundreds of thousands of housing deficits (Kabir, 2006). The situation is alarming and generating sudden fear as churches are now influencing building owners to eject their tenants to take over their apartments. The occupation range from one bedroom or three bedroom apartments in multiple apartment buildings either on long lease, contract or outright purchase from the building owners. No neighbourhood in cosmopolitan Ibadan is devoid of this phenomenon, except in the emerging higher class residential estates where there is control of church development (Kabir, 2006). As of today, the population of Ibadan has climbed to about 3 million and churches have continued to grow geometrically.

\section{SUGGESTED SOLUTIONS}

To overcome this problem, this study proposes that the Oyo State Ministry of Physical Planning and Urban Development with the Ministry of Lands, Housing and Survey in Ibadan should undertake a primary and the traditional role with the Christian Association of Nigeria (CAN) and the Nigeria Supreme Council for Islamic Affairs (NSCIA). The Ministries should engage CAN and NSCIA with a view to identify the number of churches and mosques in each residential district. At the same time, adequate resettlement and re-planning strategies must be put in place for the residents of the acquired properties, reference should be made to existing regional or local plans, and Environmental Impact Analysis of such church and mosque agglomeration must first be submitted and discussed with the stakeholders in each district.

Also, there is a need for the CAN and NSCIA to sensitize their members on the negative implications of church and mosque incursion to residential areas and to encourage them to set up a Development Control and Standardization Department within their respective organizations. All measures to improve urban planning in Ibadan will be meaningful; thus it is crucial to reverse the rattle of church depletion of housing stock through strict adherence to planning regulations and effective engagement of relevant stakeholders. It will be of utmost importance to draw attention of the Ministry of Physical Planning and Urban Development to the emergence of mega churches at the Basorun OlowoNla axis, also Lagos-Ibadan Expressway. If the trend and progression of church development continue, as it is in this corridor, Lagos-Ibadan Expressway may not be able in the next ten years to rival this pristine location in terms of traffic imbroglio and other social and economic crises. 


\section{CONCLUSION}

Town planning has become an integral and necessary portion of governance in the modern time. In the case of Ibadan, the state government which oversees the planning and development of the city has undertaken significant efforts in ensuring the city is well planned. Nevertheless, the proliferation of religious houses in the city has undermined the planning efforts of the government. However, efforts to plan and develop Ibadan in orderly manner must continue. This paper has made several proposals on how this can be achieved.

\section{ACKNOWLEDGMENT}

This work is supported Alhaji Sheik Mikail Abdul Aziz, Imam of Islamic Society of Papua New Guinea, near Australia.

\section{REFERENCES}

Adekilekun, A. L. (2001). Muslim and Islamic Law in Southern Nigeria (1988-1999). Ede: Mojoyinola Publishers.

Doi, A. R. (1984). Islam in Nigeria. Zaria: Gaskiya Corporation Limited.

Agbetola, A. S. (1999). Architectural design of the mosque in Islam: Ondo State as a case study. Oye Ogun Journal of Arts, viii, 44-54.

Shope, J. H. (1954). The need for church planning. Journal of the American Institute of Planners, 20(3), 122-124.

Akintola, I. L. (2004). An evaluation of the impact of the proliferation of churches and mosques in the Nigeria society. Insight: Journal of Religious Study, 1(2\&3), 7691.

Liadi, M. (2001). Mosques structure across Ibadan, Ibadan: Legacy Print Press.

Kabir, O. (2006). Impact of religious sites on city planning in Nigeria. Longman Press, 16-30.

Iyanda, P. (2004). Churches in the City Plan. Landsmark Publication, 25.

Joseph, W. (1997, May 21). Planning for church location, report and review. Vanguard News. 